\title{
Heterotrophic bacterial production in the Cretan Sea (NE Mediterranean)
}

\author{
France Van Wambeke a,*, Urania Christaki b ${ }^{\text {b }}$ Micheline \\ Bianchi a , Stella Psarra ${ }^{c}$, Anastasios Tselepides ${ }^{\mathrm{c}}$ \\ a Microbiologie Marine, C.N.R.S., EP 2032, Campus de Luminy, Case 907, 13288 Marseille Cedex 9, \\ France \\ ${ }^{\mathrm{b}}$ National Centre for Marine Research, Aghios Kosmas Hellinikon, 16604 Athens, Greece \\ c Institute of Marine Biology of Crete, P.O. Box 2214, Heraklion, Crete, Greece
}

\begin{abstract}
In March and September 1995, bacterial production was measured by the ${ }^{3} \mathrm{H}$-leucine method in the oligotrophic Cretan Sea (Aegean Sea, Eastern Mediterranean) in the framework of the CINCS/MTP program. Samples were obtained from four stations (a coastal, a continental shelf and 2 open-sea stations) for the construction of vertical profiles of bacterial abundance and production. Bacterial production ranged from $0.1 \mu \mathrm{g} \mathrm{C} \mathrm{m}^{-3} \mathrm{~h}^{-1}$ at $1500 \mathrm{~m}$ depth, to $82 \mu \mathrm{g}$ $\mathrm{C} \mathrm{m}^{-3} \mathrm{~h}^{-1}$ in March at $50 \mathrm{~m}$ at the coastal station. Higher bacterial integrated production was observed in March at the coastal station (131 mg C m $\mathrm{m}^{-2} \mathrm{~d}^{-1}$ for the 0-100 m layer). Bacterial production, integrated through the water-column, was similar in March and September for the open-sea stations (60-70 $\left.\mathrm{mg} \mathrm{C} \mathrm{m} \mathrm{m}^{-2} \mathrm{~d}^{-1}\right)$. Relative to production, bacterial concentrations varied little between stations and seasons ranging from $9 \times 10^{5} \mathrm{ml}^{-1}$ to $3 \times 10^{5} \mathrm{ml}^{-1}$. Relationships between bacterial biomass and bacterial production indicated seasonal differences, likely reflecting resource limitation of bacterial biomass in March (bloom situation), and predator limitation of bacterial biomass in September (post-bloom situation). (C) 2000 Elsevier Science Ltd. All rights reserved.
\end{abstract}

\section{Contents}

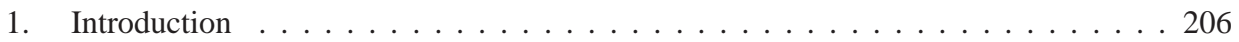

2. Materials and methods . . . . . . . . . . . . . . . 206

\footnotetext{
* Corresponding author.
} 
3. Results and discussion . . . . . . . . . . . . . . . . . . . 208

3.1. Assessment of optimal protocol . . . . . . . . . . . . . . . . 208

3.2. Vertical profiles . . . . . . . . . . . . . . . . . . . . . . . . 209

3.3. Integrated fluxes and stocks: relationships with primary producers $\ldots \ldots \ldots 211$

Acknowledgements . . . . . . . . . . . . . . . . . . . . . . . . . 214

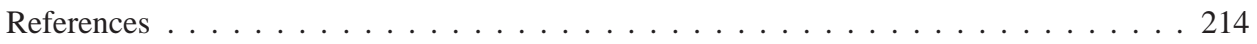

\section{Introduction}

Microbial food webs have been the focus of many studies over the last two decades, following the seminal paper of Pomeroy (1974). In general terms, Dortch and Packard (1989) proposed that food webs in eutrophic waters are dominated by the biomass of primary producers while food webs in oligotrophic waters are dominated by the biomass of decomposers. In oligotrophic oceans, bacterial biomass and activities can be the major factor in food web structure, controlling nutrient cycling pathways, and biochemical dynamics (Cho \& Azam, 1990).

Of all oligotrophic marine environments, the Eastern Mediterranean is perhaps the system for which the least amount of data exist. Apart from the studies of Zohary and Robarts (1992) and Robarts, Zohary, Waiser and Yacobi (1996) in the Levantine Basin, there are no other published data, to our knowledge, dealing with bacterial production in the area. Given the absence of any bacterial production measurements in the extremely oligotrophic Southern Aegean Sea, the main objective of our study was to quantify this parameter and to assess the fluxes of carbon cycling through the microbial food web within the pelagic zone. The results are to be integrated in the framework of CINCS/MTP program, whose main topic was the benthic-pelagic coupling in the Cretan Sea (South Aegean Sea, NE Mediterranean).

In pelagic processes, the proportion of primary production cycling through the microbial loop can be used as an index of the coupling between heterotrophic and autotrophic processes in the water column (Cole, Findlay \& Pace, 1988; Hoch \& Kirchman, 1993), i.e. as an indicator of the possible fate of phytoplankton-derived material in the Cretan Sea. To facilitate flux comparisons in terms of carbon, special attention was given to the method used (incorporation of ${ }^{3} \mathrm{H}$-leucine) which can be directly converted into carbon units. Time and concentration series experiments were carried out to measure bacterial production while testing the possibility of unspecific labeling. Bacterial production and biomass were investigated during March (spring situation) and September 1995 (post-bloom situation), along the transect lying northwards of the city of Heraklion (Crete, Greece).

\section{Materials and methods}

Bacterial production was studied during two cruises in March (February 28-March 2) and September (5-7) 1995, aboard the R/V Philia. Samples were collected along 
a transect along $25^{\circ} 06^{\prime} \mathrm{E}$ at station D2 (coastal station, $100 \mathrm{~m}$ max. depth $35^{\circ} 23^{\prime}$ $\mathrm{N}$ ) and D4 (continental slope station, $540 \mathrm{~m}$ max. depth, $35^{\circ} 30^{\prime} \mathrm{N}$ ), where primary production was simultaneously measured, also at two open-sea stations D6 (940 m

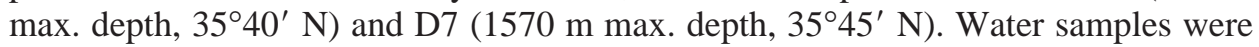
taken around midday in 51 Niskin bottles wherever possible from standard depths of $(5,10,20,30,50,75,100,200,300,500,1000$ and $1500 \mathrm{~m})$. These were processed immediately onboard.

Seawater samples for bacteria enumeration were preserved in buffered formalin $\left(2 \% \mathrm{w} / \mathrm{v}\right.$ final concentration) and stored at $4{ }^{\circ} \mathrm{C}$. Slides for microscopical counts were prepared (including filtration and DAPI staining, $2500 \mu \mathrm{g} \mathrm{l}^{-1}$ final concentration) within $24 \mathrm{~h}$ of sampling. Slides were stored frozen until examination with an epifluorescence microscope equipped with an image analysis system (Van Wambeke, 1995). Cell numbers were converted to biomass, assuming each cell contained 20 fg C (Lee \& Fuhrman, 1987).

Bacterial production was estimated by the ${ }^{3} \mathrm{H}$-leucine approach (Kirchman, Newell \& Hodson, 1986). For each depth, duplicate samples and a control were incubated with $1 \mathrm{nM} \mathrm{L-}\left[4,5{ }^{3} \mathrm{H}\right]$-leucine (specific activity $128 \mathrm{Ci} \mathrm{mmol}^{-1}$ in March, $158 \mathrm{Ci}$ $\mathrm{mmol}^{-1}$ in September) $+18 \mathrm{nM}$ non radioactive leucine. All subsamples were incubated in the dark, at sea surface temperatures (around $15^{\circ} \mathrm{C}$ in March and $26^{\circ} \mathrm{C}$ in September) in a flow-through on-deck incubator flushed with seawater drawn from $3 \mathrm{~m}$ depth. The volume and the incubation time varied, according to the sampling depth and the expected production rates: $20-150 \mathrm{ml}$ and 2-12 hours, respectively. At the end of incubation samples were killed with formalin ( $2 \%$ final concentration).

The duplicates and the control were filtered through $0.2 \mu \mathrm{m}$ Millipore filters $(25$ mm diameter, Type GS). When the vacuum was turned off, the funnels were filled with $10 \mathrm{ml}$ ice-cold 5\% trichloroacetic acid (TCA), held for $10 \mathrm{~min}$ and refiltered. The filters were then washed 3 times with ice-cold 5\% TCA. Various authors have shown that there are no significant differences in results obtained after the use of either cold or hot TCA for protein precipitation (Servais, 1995; Chin-Leo \& Kirchman, 1988; Riemann \& Azam, 1992). We therefore used the cold-TCA procedure instead of hot-TCA as originally described with the leucine method (Kirchman et al., 1986), because it was faster and easier to use routinely at sea. Ethyl acetate (1 $\mathrm{ml}$ ) was added to the vials to dissolve the filters and the samples were radioassayed with BECKMAN LS 1800 Scintillation Counter in $10 \mathrm{ml}$ of fluor (PCS, Amersham).

Bacterial production was calculated according to Kirchman (1993) from ${ }^{3} \mathrm{H}-\mathrm{leu}-$ cine incorporation rates. Determination of the isotopic dilution factor is described below. Because all samples were incubated at surface water temperature in a water bath set up on board, leucine incorporation rates were corrected for temperature using an Arrhenuis equation experimentally determined using bacterial production data from the Atlantic ocean $\left(Q_{10}=2.6\right)$.

On each cruise, time series experiments were carried out on surface waters where activity was likely to be high and in deeper waters where activity was likely to be lower. The aim was to determine the appropriate incubation time for different levels of activity. Concentration kinetics were also examined in order to verify that the concentration of leucine added $(19 \mathrm{nM})$ was sufficient to saturate incorporation and 
to check whether or not isotopic dilution was negligible. For this purpose, constant concentrations of labeled leucine $(1 \mathrm{nM})$ and five different concentrations of nonradioactive leucine $(1.8-37 \mathrm{nM})$ were added to different subsamples. The plot of $T / f$ (radioactive leucine incorporated per unit time) against leucine concentration has permitted the calculation of an index of isotopic dilution ( $X$ intercept) and the $V \max$ (inverse of the slope, Pollard \& Moriarty, 1984; Kirchman et al., 1986). During September 1995, the possibility of incorporation of the label in the lipid fraction was examined. At some depths, the radioactivity retained on two sets of filters was compared. One set was rinsed with TCA only while the second set was further rinsed with ice-cold $80 \%$ ethanol (Wicks \& Robarts, 1988).

\section{Results and discussion}

\subsection{Assessment of optimal protocol}

During both cruises, ${ }^{3} \mathrm{H}$-leucine incorporation into bacterial protein was linear over the first $4 \mathrm{~h}$ of incubation in the surface waters $(5 \mathrm{~m}$ and $50 \mathrm{~m}$, stations D2 and D4). For the deeper layers, incorporation was linear up to $12 \mathrm{~h}$ in March $(300 \mathrm{~m}$, D4) and September (300 m D4, $1500 \mathrm{~m} \mathrm{D7).} \mathrm{The} \mathrm{concentration} \mathrm{kinetics} \mathrm{followed}$ a Michaelis-Menten model and the transformed data showed the expected linear regression in March (5, 50 and $300 \mathrm{~m}$ stations D2 and D4). However, a continuous increase of leucine incorporation rate with increased concentration of leucine was observed in September in the deeper samples. This artifact has already been described in estuarine samples, where leucine was not saturated even up to $333 \mathrm{nM}$ concentration (Hollibaugh \& Wong, 1992). This can be explained by the presence of bacteria (such as attached bacteria) adapted to high concentrations of leucine or by leucine assimilation by other micro-organisms (Logan \& Fleury, 1993). In all other interpretable cases, results showed that, even with a concentration of $18 \mathrm{nM}$ of leucine added, more than $90 \%$ of the $V \max$ was reached, indicating conditions of saturation. The degree of participation of the leucine added to the leucine incorporation rate in proteins was always more than $90 \%$ for the upper layers (Table 1), showing negligible isotopic dilution by de novo synthesis and/or natural leucine concentration. In con-

Table 1

Kinetic parameters calculated from the isotopic dilution plots. DP is the degree of participation of added leucine to the leucine incorporation rate and ID is the isotopic dilution factor

\begin{tabular}{lllll}
\hline & $\begin{array}{l}V \max \\
\left(\mathrm{pmole} \mathrm{l}^{-1} \mathrm{~h}^{-1}\right)\end{array}$ & $X$ intercept $(\mathrm{nM})$ & DP (\%) & ID \\
\hline March, D4, 5 m & 9.1 & 1.14 & 94 & 1.06 \\
September, D2, 5 m & 3.7 & 1.64 & 92 & 1.08 \\
September, D2, 50 m & 9.3 & 2.24 & 89 & 1.12 \\
March, D4, 300 m & 0.55 & 11.1 & 62 & 1.61 \\
\hline
\end{tabular}


trast, the degree of participation (DP) value was about $62 \%$ for deeper layers. Thus, we applied an isotopic dilution of 1 in both seasons for samples down to $200 \mathrm{~m}$, and a factor 1.6 for deeper layers.

The lipid labeling was checked during the second cruise, in September at station D7. The results showed good agreement of leucine incorporation rates at all depths tested. Activities were not statistically different with or without an additional ethanol rinse (Wilcoxon test, 5 pairs of data, $p=0.89$ ) implying no lipid incorporation of radioactive leucine.

\subsection{Vertical profiles}

Bacterial production in the surface layer varied considerably (Fig. 1). Generally, peaks of bacterial production and bacterial abundance coincided with primary production peaks (Psarra, Tselepides \& Ignatiades, 2000). The maximum value of bacterial production was observed at the coastal station D2, where it reached $82 \mu \mathrm{g} \mathrm{C}$ $\mathrm{m}^{-3} \mathrm{~h}^{-1}$ at $50 \mathrm{~m}$ in March, and showed no decrease with depth (Fig. 1). Overall, bacterial production in the surface layers of the coastal and continental shelf stations

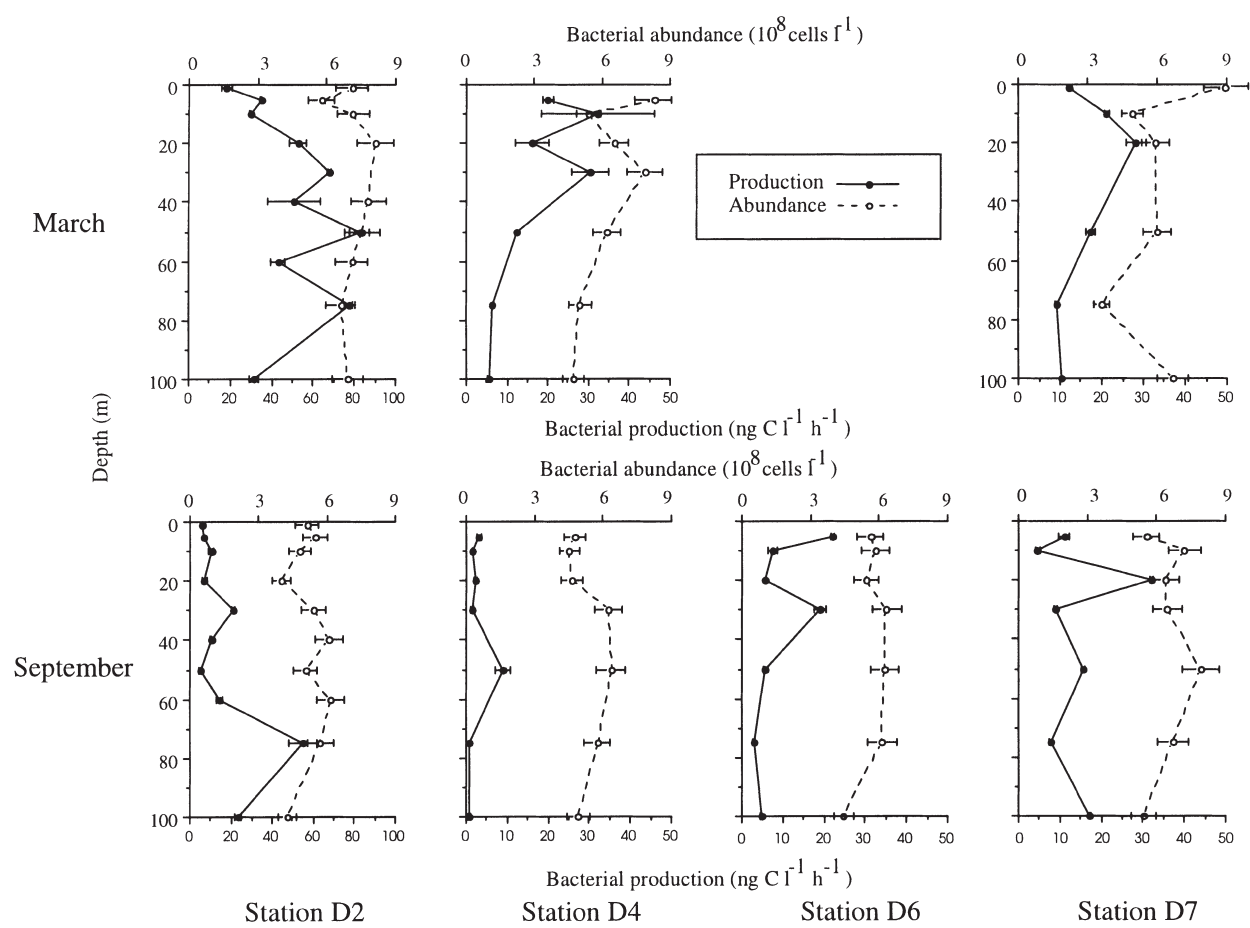

Fig. 1. Vertical profiles of bacterial production (solid line) and bacterial abundance (dotted line) in the upper $100 \mathrm{~m}$ layers at stations D2, D4, D6 and D7. Error bars represent difference between duplicates for bacterial production, and standard deviation for bacterial abundance. 
was about half that reported in the Western Mediterranean (Christaki, Van Wambeke, Christou, Conan \& Gaudy, 1996; Fernandez, Bianchi \& Van Wambeke, 1994).

In the deep water stations, maximum bacterial production always occurred in the surface layers, although in some cases high values were also recorded deeper in the water column (e.g. $200 \mathrm{~m} \mathrm{D} 4,500$ and $1500 \mathrm{~m} \mathrm{D7,} \mathrm{September,} \mathrm{Table} \mathrm{2).} \mathrm{At} \mathrm{these}$ stations, production in terms of cells per h, calculated assuming $20 \mathrm{fg} \mathrm{C}$ cell $^{-1}$ (Lee \& Fuhrman, 1987), was low (0.1-1.0 $10^{9}$ cells $\left.\mathrm{m}^{-3} \mathrm{~h}^{-1}\right)$ and similar to those reported by Zohary and Robarts (1992): 0.1-0.5 $10^{9}$ cells $\mathrm{m}^{-3} \mathrm{~h}^{-1}$ ). Bacterial generation times, calculated from standing stocks and production data in terms of cells $\mathrm{h}^{-1}$, were quite long, especially in the deeper layers where generation times may exceed 100 days. Similar results were also reported by Zohary and Robarts (1992), who assumed that this was an artefact originating from the use of a theoretical conversion factor for thymidine incorporation. While the leucine method allows for calculation of bacterial production directly from leucine incorporation rates independent of the cell biovolume (Simon \& Azam, 1989), our calculations are sensitive to the conversion factor employed for cell carbon.

The long turn-over times of bacterial carbon may be explained in part by the possibility that a high percentage of the bacteria present in the deeper waters are inactive (Bianchi \& Giuliano, 1996). Another possible source of error in surface samples of oligotrophic waters may be that the heterotrophic bacterial biomass may be overestimated because Prochlorococcus nuclei may be included in the counts of heterotrophic bacteria. For example, in central North Pacific Ocean Prochlorococcus contribution to total bacterial counts was 31\% (Campbell, Nolla \& Vaulot, 1994) and 15-20\% in Central Equatorial Pacific (Landry, Kirshtein \& Constantinou, 1996). Pigments were analyzed by HPLC during METEOR cruise in Cretan Sea (Vidussi, personal communication). Two stations were sampled at $35.8^{\circ} \mathrm{N} 24.1^{\circ} \mathrm{E}$, and $35.8^{\circ} \mathrm{N}$ $24.2^{\circ} \mathrm{E}$ in January 1995 . Concentrations of divynylchlorophyll $a$ ranged from 11 to

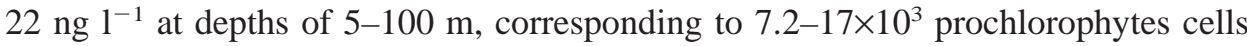
$\mathrm{ml}^{-1}$ (assuming a minimum conversion factor of $1.5 \mathrm{fg}$ div-chl a per cell (Caillau, Claustre, Vidussi, Marie \& Vaulot, 1996)). For the eastern Mediterranean, the little data available on concentrations of Prochlorococcus suggest that peak concentrations

Table 2

Bacterial production $\left(\mu \mathrm{g} \mathrm{C} \mathrm{m}{ }^{-3} \mathrm{~h}^{-1}\right)$ in deep layers (100 $\mathrm{m}$ to the bottom). Mean \pm half of the difference between duplicates. M: March, S: September

\begin{tabular}{|c|c|c|c|c|c|}
\hline Depth (m) & D4 M & D7 M & D4 S & D6 S & D7 S \\
\hline 100 & $5.5 \pm 0.1$ & $10.4 \pm 0.1$ & $0.8 \pm 0.3$ & $4.7 \pm 0.1$ & $17.3 \pm 0.2$ \\
\hline 200 & $5.5 \pm 0.2$ & $0.64 \pm 0.3$ & $16.6 \pm 0.5$ & $1.4 \pm 0.1$ & $3.9 \pm 0.5$ \\
\hline 300 & $2.1 \pm 0.3$ & $1.4 \pm 0.1$ & $3.1 \pm 0.7$ & $2.4 \pm 0.4$ & $18.3 \pm 2.3$ \\
\hline 500 & $0.26 \pm 0.05$ & $0.82 \pm 0.05$ & & $2.1 \pm 0.8$ & $25.8 \pm 1.6$ \\
\hline 900 & & & & $3.8 \pm 0.6$ & \\
\hline 1000 & & $0.35 \pm 0.05$ & & & $4.2 \pm 0.8$ \\
\hline 1500 & & $0.12 \pm 0.05$ & & & $11.7 \pm 3.4$ \\
\hline
\end{tabular}


of $10^{4}$ cells $\mathrm{ml}^{-1}$ occur at depths of about $100 \mathrm{~m}$ (Li, Zohary, Yacobi \& Wood, 1993; Vaulot, Partensky \& Marie, 1997).

Based on Prochlorococcus abundances of $10^{4} \mathrm{ml}^{-1}$, it appears unlikely that our estimates of heterotrophic bacterial abundances would be over by more than $15 \%$. Nonetheless, while the leucine incorporation method provided estimates of bacterial production in the study area, the existing abundance data do not permit accurate calculation of specific bacterial growth and doubling times.

During the September '95 experiment, there was a considerable difference between in situ and incubation temperature for the deeper layers. In spite of the temperature correction $\left(Q_{10}=2.6\right.$, see methods), some peaks of bacterial production were obtained at station D7 $(500 \mathrm{~m}, 1500 \mathrm{~m})$. Nevertheless, measured bacterial production in the deep layers of station D6 was low (Table 2, D6 S). Thus, these peaks were not systematically observed. Some of the high values observed in the deep water column during September corresponded to maxima in the concentrations of particulate organic carbon (118 and $110 \mu \mathrm{g} \mathrm{C} 1^{-1}$ at $500 \mathrm{~m} \mathrm{D7}$ and $200 \mathrm{~m} \mathrm{D} 4$, respectively (Tselepides, Zarvakis, Polychronaki, Danovaro \& Chronis, 2000)). This suggests that relatively high values of bacterial production in deeper samples can also be attributed to micro-niches (particles and/or colloidal material colonized by productive bacteria (Azam, Smith, Steward \& Hagström, 1993; Turley, Lochte \& Lampitt, 1995)), and/or lateral intrusion of different water masses, such as the Transition Mediterranean Waters (TMW (Georgopoulos, Chronis, Zervakis, Likousis, Poulos \& Iona, 2000)).

\subsection{Integrated fluxes and stocks: relationships with primary producers}

One characteristic feature of this oligotrophic system was the dominance of bacterial biomass over phytoplankton biomass. Except for the coastal station in March, calculated bacterial biomass was consistently higher than calculated autotrophic biomass (Fig. 2); this observation is unaffected even if the maximum allowance is made for the potential overestimate of bacterial biomass that may result from including Prochlorococcus. Robarts et al. (1996) found an opposite relationship in the Levantine basin, while using integrated data and the same chlorophyll/carbon ratios we employed. Their bacterial counts never exceeded $3.9 .10^{8} 1^{-1}$, and $83 \%$ of their bacterial population was assumed to be cocciform containing only $15 \mathrm{fg} \mathrm{C}$. The controversy about the significance of this ratio is important. Bacterial biomass is controlled by shifts between bottom-up and top-down control. So bacteria, which do not sink, constitute crucial reservoirs for both particulate nitrogen (Danovaro et al., 2000) and phosphorus being maintained in the euphotic zone. Moreover, DOC may accumulate (Thingstad, Hagstron \& Rassoulzadegan, 1997). Maintaining a continuum of physiological states and a high bacterial diversity in a damped biomass stock could benefit bacteria in oligotrophic systems in which labile nutrients appear during small-scale rapid events.

There are many problems in making such calculations, for example: i) the high variability of the chlorophyll/carbon ratio in oligotrophic and stratified conditions (Claustre \& Marty, 1995); ii) the alternative ways to calculate carbon per bacteria conversion factor (Norland, 1993); and iii) the recent debate on the significance of 


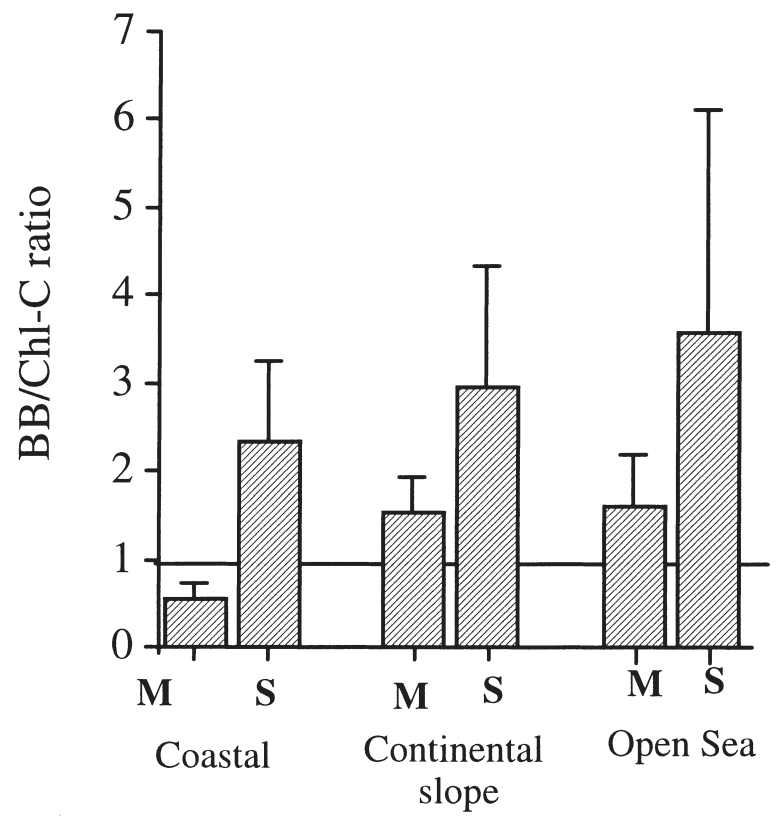

Fig. 2. Average BB/C-Chl a ratios in March (M) and September (S) BB: Bacterial biomass, C-Chl $a$ : carbon equivalent of chlorophyll $a$. Conversion factors were: $20 \mathrm{fg} \mathrm{C}$ per bacteria and $\mathrm{C} / \mathrm{Chl}=50$. Data taken into account corresponded to layers where Chl $a$ was higher than $0.03 \mu \mathrm{g} \mathrm{Chl} 1^{-1}$, i.e. $n=2-10$ depending on the station.

bacterial epifluorescence counts concerning active-inactive bacteria and counting of prochlorophytes as heterotrophic bacteria (Campbell et al., 1994; Zweifel \& Hagström, 1995; Sieracki, Haugen \& Cucci, 1995; Landry et al., 1996).

In the euphotic zone, a higher value of integrated bacterial production was recorded at the coastal station during the bloom (March), and a lower value in September, during a post-bloom situation (Table 3). In open sea stations, the magnitude of integrated bacterial production was characteristic of highly oligotrophic conditions. In the Levantine Basin, very low bacterial production, integrated through $200 \mathrm{~m}$, has been noted previously 8-43 $\mathrm{mg} \mathrm{C} \mathrm{m}^{-2} \mathrm{~d}^{-1}$ (Zohary \& Robarts, 1992; Robarts et al., 1996).

Table 3

Integrated bacterial production $\left(\mathrm{mg} \mathrm{C} \mathrm{m}^{-2} \mathrm{~d}^{-1}\right)$ over the upper layer $(0-100 \mathrm{~m})$ and the whole water column. M: March, S: September

\begin{tabular}{llllllll}
\hline Stations & D2 & & D4 & \multicolumn{3}{c}{ D6 } & D7 \\
\hline Date & M & S & M & S & S & M & S \\
0-100 m & 131 & 51.1 & 36.5 & 7.4 & 19.5 & 40.1 & 32.1 \\
Whole water column & 131 & 51.1 & 64.5 & 61.9 & 70.5 & 70.9 & 465 \\
Depth of integrated value & $100 \mathrm{~m}$ & $100 \mathrm{~m}$ & $500 \mathrm{~m}$ & $500 \mathrm{~m}$ & $900 \mathrm{~m}$ & $1500 \mathrm{~m}$ & $1500 \mathrm{~m}$ \\
\hline
\end{tabular}


Differences between the two seasons were marked at the coastal station but less extreme at the continental slope station D4. At D4, the peak of bacterial production observed in September had deepened consistently with the chlorophyll $a$ maximum (Psarra et al., 2000). Integrated bacterial production in the whole water-column was almost equal for stations D4, D6 and D7 at both seasons, except for the high value observed during September in D7, due to high values measured in the deeper layer (Table 2).

The relative importance of food supply or grazing as factors controlling bacteria were examined using the approach outlined by Billen, Servais and Beckevort (1990). The method employs bacterial production as an index of the input flux of dissolved organic matter, but only the data from the March cruise yielded a significant regression (Fig. 3). The slope of the regression (0.26) was close to the value cited for a large data set for the open ocean (0.28 (Ducklow, 1992)) suggesting bottomup control is weak. Our data was obtained over a small spatial and temporal scale, the extent of which has to be taken into account in the control of bacterial biomass (Billen et al., 1990; Ducklow, 1992; Dufour \& Torreton, 1996). However, our data range over three orders of magnitude for bacterial production and two orders of magnitude for bacterial biomass. The absence of correlation in September may indicate, as suggested by Ducklow (1992), a seasonal progression from a resource limi-

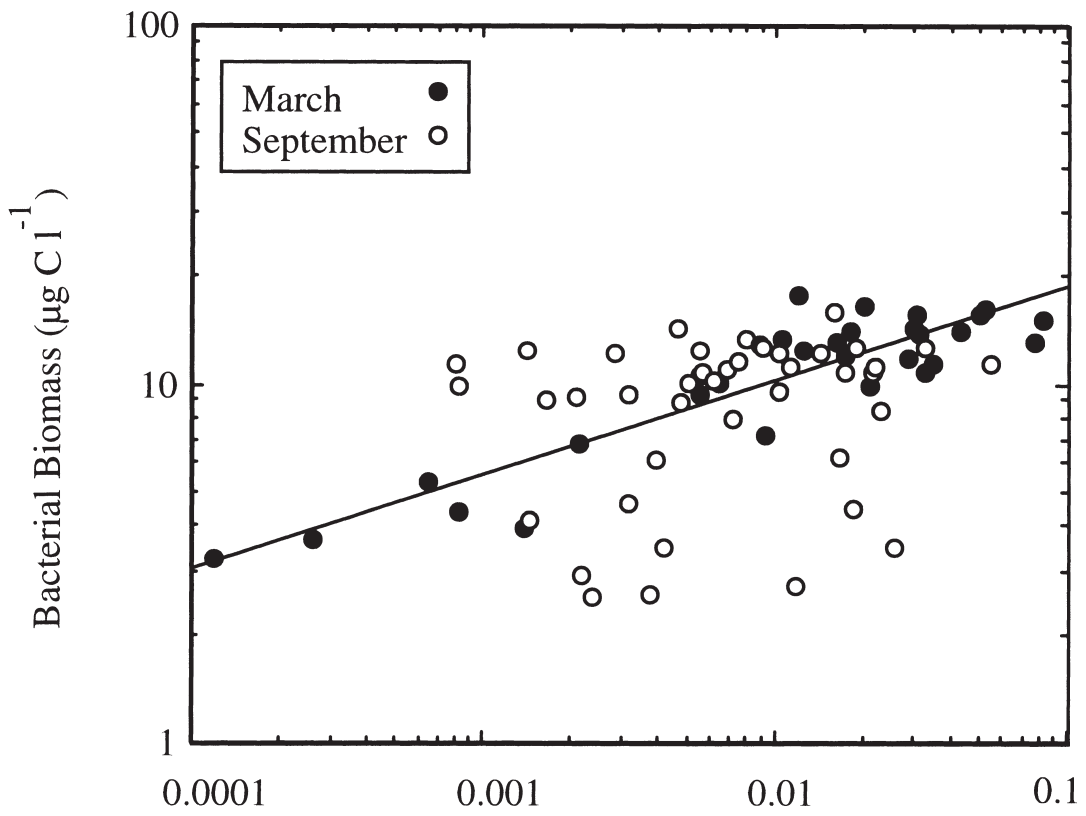

Bacterial Production $\left(\mu \mathrm{g} \mathrm{Cl} \mathrm{l}^{-1} \mathrm{~h}^{-1}\right)$

Fig. 3. Regression between bacterial biomass and bacterial production. The line is the least-squares fit to the $\log$-transformed March data; $\log$ (biomass)=1.53+0.26 log (production); $r=0.9 ; n=29$. 
tation of bacterial biomass in March (bloom situation) to predator limitation in September.

An index of the fraction of the photosynthetically produced carbon that enters the microbial food web in the euphotic zone $(0-100 \mathrm{~m})$ can be estimated by the ratio $\mathrm{BCD} / \mathrm{PP}$, where bacterial carbon demand (BCD) is calculated from integrated bacterial production, assuming 50\% as bacterial growth efficiency, and PP is the integrated primary production (Psarra et al., 2000). At the coastal station, regardless of the season, bacterial carbon demand was very close to phytoplankton production $(\mathrm{BCD} / \mathrm{PP}=1.03$ in March, 0.83 in September). A ratio of $\mathrm{BCD}$ to PP equal to 1 does not necessarily imply that all primary production is dissipated by the microbial loop. BCD and PP were not necessarily coupled on the time scale of our study and bacterial growth could also be sustained by other carbon sources (Azam et al., 1993). In contrast, at the continental slope station D4, this ratio was only 0.35 during March and 0.37 during September. According to some recent studies on seawater cultures, bacterial growth efficiencies in an oligotrophic sea should be lower than 0.5, reaching 0.1-0.3 (Kirchman, Suzuki, Garside \& Ducklow, 1991; Carlson \& Ducklow, 1996); this suggests that, more than half of the primary production may have been dissipated by mineralization in the upper layers of the open Cretan Sea during the two study periods. Future research in this area should focus on the seasonal switch of the main parameters controlling bacterial production and phytoplankton-bacteria coupling among seasons, i.e. food resources (mineral and organic) and predation.

\section{Acknowledgements}

The authors acknowledge the support provided by the crew of R/V Philia. We thank Elena Dafnomili for providing us with the chlorophyll data. We also acknowledge an anonymous reviewer for his suggestions that improved the manuscript. This research was undertaken in the framework of the Mediterranean Targeted Projects (MTP) EMPS and CINCS. We acknowledge the support from the European Commission's Marine Science and Technology (MAST) Program under contract MAS2CT94-0090 and MAS2-CT94-0092. This paper was accepted in 1997.

\section{References}

Azam, F., Smith, D. C., Steward, G. F., \& Hagström, Å. (1993). Bacteria-organic matter coupling and its significance for oceanic carbon cycling. Microbial Ecology, 28, 167-179.

Bianchi, A., \& Giuliano, L. (1996). Enumeration of viable bacteria in marine pelagic environments. Applied and Environmental Microbiology, 62, 174-177.

Billen, G., Servais, P., \& Beckevort, S. (1990). Dynamics of bacterioplankton in oligotrophic and eutrophic aquatic environments: bottom-up or top-down control? Hydrobiologia, 207, 37-42.

Caillau, C., Claustre, H., Vidussi, F., Marie, D., \& Vaulot, D. (1996). Carbon biomass, and growth rates as estimated from 14C pigment labeling, during photoacclimatation in Prochlorococcus CCMP 1378. Marine Ecology Progress Series, 145, 209-221.

Campbell, L., Nolla, H. A., \& Vaulot, D. (1994). The importance of Prochlorococcus to community structure in the central Pacific Ocean. Limnolology and Oceanography, 39, 954-961. 
Carlson, C. A., \& Ducklow, H. W. (1996). Growth of bacterioplankton and consumption of dissolved organic carbon in the Sargasso Sea. Aquatic Microbial Ecology, 10, 69-85.

Chin-Leo, G., \& Kirchman, D. (1988). Estimating bacterial production in marine waters from the simultaneous incorporation of thymidine and leucine. Applied and Environmental Microbiology, 54, 1934-1939.

Cho, B. C., \& Azam, F. (1990). Biogeochemical significance of bacterial biomass in the ocean's euphotic zone. Marine Ecology Progress Series, 63, 253-259.

Christaki, U., Van Wambeke, F., Christou, E. D., Conan, P., \& Gaudy, R. (1996). Food web structure variability in the surface layer, at a fixed station influenced by the North Western Mediterranean Current. Hydrobiologia, 321, 145-153.

Claustre, H., \& Marty, J.-C. (1995). Specific phytoplankton biomasses and their relation to primary production in the tropical North Atlantic. Deep-Sea Research I, 42, 1475-1493.

Cole, J. J., Findlay, S., \& Pace, M. L. (1988). Bacterial production in fresh and saltwater ecosystems: a cross - system overview. Marine Ecology Progress Series, 43, 1-10.

Dortch, Q., \& Packard, T. (1989). Differences in biomass structure between oligotrophic and eutrophic marine ecosystems. Deep-Sea Resarch, 36, 223-240.

Danovaro, R., Dell'anno, A., Pusceddu, A., Marrale, D., Della Croce, N., Fabiano, M., \& Tselepides, A. (2000). Biochemical composition of pico-, nano- and micro-particulate organic matter and bacterioplankton biomass in the oligotrophic Cretan Sea (NE Mediterranean). Progress in Oceanography, 46, 279-310.

Ducklow, H. W. (1992). Factors regulating bottom-up control of bacteria biomass in open ocean plankton communities. Archiv für Hydrobiologie Beiheft Ergebnisse der Limnologie, 37, 207-217.

Dufour, P., \& Torreton, J. P. (1996). Bottom-up control of bacterioplankton from eutrophic to oligotrophic sites in the North-Eastern tropical Atlantic Ocean. Deep-Sea Research I, 43, 1305-1320.

Fernandez, M., Bianchi, M., \& Van Wambeke, F. (1994). Bacterial biomass, heterotrophic production and utilization of dissolved organic matter photosynthetically-produced in the Almeria-Oran front. Journal of Marine Systems, 5, 313-325.

Georgopoulos, D., Chronis, G., Zervakis, V., Likousis, V., Poulos, S., \& Iona, A. (2000). Hydrology and circulation in the Southern Cretan Sea during the CINCS experiment (May 1994-September 1995). Progress in Oceanography, 46, 89-112.

Hoch, M. P., \& Kirchman, D. L. (1993). Seasonal and inter-annual variabiliy in bacterial production and biomass in a temperate estuary. Marine Ecology Progress Series, 98, 283-285.

Hollibaugh, J. T., \& Wong, P. S. (1992). Ethanol-extractable pools and the incorporation of thymidine, L-leucine and other substrates by bacterioplankton. Canadian Journal of Microbiology, 38, 605-613.

Kirchman, D. L., Suzuki, Y., Garside, C., \& Ducklow, H. W. (1991). High turnover rates of dissolved organic carbon during a spring phytoplankton bloom. Nature, London, 352, 612-614.

Kirchman, D. L. (1993). Leucine incorporation as a measure of biomass production by heterotrophic bacteria. In P. F. Kemp, B. F. Sherr, E. B. Sherr, \& J. J. Cole, Handbook of methods in aquatic microbial ecology (pp. 509-512). Ann Arbor: Lewis Publishers.

Kirchman, D. L., Newell, S. Y., \& Hodson, R. E. (1986). Incorporation versus biosynthesis of leucine: implications for measuring rates of protein synthesis and biomass production by bacteria in marine systems. Marine Ecology Progress Series, 32, 47-59.

Landry, M. R., Kirshtein, J., \& Constantinou, J. (1996). Abundances and distributions of picoplankton populations in the central equatorial Pacific from $12^{\circ} \mathrm{N}$ to $12^{\circ} \mathrm{S}, 140^{\circ} \mathrm{W}$. Deep-Sea Research I, 43, 871-890.

Lee, S., \& Fuhrman, J. A. (1987). Relationships between biovolume and biomass of naturally derived marine bacterioplankton. Applied Environmental Microbiology, 53, 1298-1303.

Li, W. K. W., Zohary, T., Yacobi, Y. Z., \& Wood, A. M. (1993). Ultraphytoplankton in the eastern Mediterranean Sea: towards deriving phyoplankton biomass from flow cytometric measurements of abundance, fluorescence and light scatter. Marine Ecology Progress Series, 102, 79-87.

Logan, D. E., \& Fleury, R. C. (1993). Multiphasic kinetics can be an artefact of the assumption of saturable kinetics for microorganisms. Marine Ecology Progress Series, 102, 115-124.

Norland, S. (1993). The relationship between biomass and volume of bacteria. In P. F. Kemp, B. F. Sherr, 
E. B. Sherr, \& J. J. Cole, Handbook of methods in aquatic microbial ecology (pp. 303-307). Ann Arbor: Lewis Publishers.

Pollard, P. C., \& Moriarty, D. (1984). Validity of the tritiated thymidine method for estimating bacterial growth rates: measurement of isotope dilution during DNA synthesis. Applied and Environmental Microbiology, 48, 1076-1083.

Pomeroy, L. R. (1974). The ocean's food web, a changing paradigm. Bioscience, 24, 499-504.

Psarra, S., Tselepides, A., \& Ignatiades, L. (2000). Primary productivity in the oligotrophic Cretan Sea (NE Mediterranean): seasonal and interannual variability. Progress in Oceanography, 46, 187-204.

Riemann, B., \& Azam, F. (1992). Measurements of bacterial protein synthesis in aquatic environments by means of leucine incorporation. Marine Microbial Food Webs, 6, 91-105.

Robarts, R. D., Zohary, T., Waiser, M. J., \& Yacobi, Y. Z. (1996). Bacterial abundance, biomass, and production in relation to phytoplankton biomass in the Levantine Basin of the southeastern Mediterranean Sea. Marine Ecology Progress Series, 137, 273-281.

Servais, P. (1995). Measurement of the incorporation rates of four amino acids into proteins for estimating bacterial production. Microbial Ecology, 29, 115-128.

Sieracki, M. E., Haugen, E. M., \& Cucci, T. L. (1995). Overestimation of heterotrophic bacteria in the Sargasso Sea: direct evidence by flow and imaging cytometry. Deep-Sea Research I, 42, 1399-1409.

Simon, M., \& Azam, F. (1989). Protein content and protein synthesis rates of planktonic marine bacteria. Marine Ecology Progress Series, 51, 201-213.

Thingstad, T. F., Hagstrom, A., \& Rassoulzadegan, F. (1997). Accumulation of degradable DOC in surface waters: is it caused by a malfunctioning microbial loop? Limnology and Oceanography, 42, 398-404.

Tselepides, A., Zervakis, V., Polychronaki, T., Danovaro, R., \& Chronis, G. (2000). Distribution of nutrients and particulate organic matter in relation to the prevailing hydrographic features of the Cretan Sea (NE Mediterranean). Progress in Oceanography, 46, 113-142.

Turley, C. M., Lochte, K., \& Lampitt, R. S. (1995). Transformations of biogenic particles during sedimentation in the northeastern Atlantic. Philosophical Transactions of the Royal Society, London, 348, 179-189.

Van Wambeke, F. (1995). Numération et taille des bactéries planctoniques au moyen de l'analyse d'images couplée à l'épifluorescence. Océanis, 21, 113-124.

Vaulot, D., Partensky, F., \& Marie, D. (1997). Populations picoplanctoniques. In: Campagne MINOS, recueil de données, Le Suroit, 21 mai-29 juin 1996. IFREMER, MATER (MAST III).

Wicks, R. J., \& Robarts, R. D. (1988). An ethanol extraction requirement for the purification of protein labelled with ${ }^{3} \mathrm{H}$-leucine in aquatic bacterial production studies. Applied and Environmental Microbiology, 54, 3191-3193.

Zohary, T., \& Robarts, R. D. (1992). Bacterial numbers, bacterial production and heterotrophic nanoplankton abundance in a warm core eddy in the Eastern Mediterranean. Marine Ecology Progress Series, 84, 133-137.

Zweifel, U., \& Hagström, A. (1995). Total counts of marine bacteria include a large fraction of nonnucleoid-containing bacteria (Ghosts). Applied and Environmental Microbiology, 61, 2180-2185. 